\title{
Slope processes and related risk appearance within the Icelandic Westfjords during the twentieth century
}

\author{
A. Decaulne \\ Géolab, Clermont-Ferrand cedex, France \\ Received: 7 September 2004 - Revised: 1 March 2005 - Accepted: 15 March 2005 - Published: 29 March 2005 \\ Part of Special Issue "Multidisciplinary approaches in natural hazard and risk assessment"
}

\begin{abstract}
In North-western Iceland, records of slope processes were increasing during the twentieth century. Few dramatic events during the last decades highlighted the danger due to slope dynamics, leaving local populations in a risk situation that was merely unknown before 1970 . The recent snow-avalanche, debris-flow and rock-fall activity underlined that the most frequent processes are not these with the largest human impact. In fact, the most catastrophic events were the extreme ones, following directly from a low frequency and a high magnitude. The purpose of this paper is to draw a parallel history of natural hazard and residence spatial extension, for an accurate understanding of the present-day risk situation, as the population growth markedly increased during the same time. Different quantitative and qualitative methods are applied. Geomorphological investigations locate the main threaten areas, in the path of slope processes release evidences, i.e. suitable slope morphology and/or inherited/actual forms. By a collection of dating data, as historic records and lichenometrical analysis, the frequency of given magnitude events is known. Climatic analysis clarifies the triggering meteorological conditions of slope processes and offers an overview of climate fluctuation during the investigated period; wind speed and direction is critical to hazardous snow-avalanche departure and snowmelt is crucial for debris-flow release. The findings clearly indicate that a combination of spatial expansion of inhabited areas and a lack of slope processes knowledge at the expansion time led to a recent and progressive risk appearance due to snow avalanches (including slush flows), debris flows and rock fall in most towns and villages of North-western Iceland.
\end{abstract}

\section{Introduction}

During the last century, coastal villages and urban nuclei of northwestern, northern and eastern Iceland have been

Correspondence to: A. Decaulne

(armld@yahoo.fr) severely concerned by recurrent snow-avalanche and debrisflow activity, its catastrophic effects being on the increase with time (Decaulne, 2004b). This paper aims to highlight the appearance of risk due to these slope processes, especially in the fjords area of northwestern Iceland, during the twentieth century, based on the study of the parallel history of natural hazards and residence extension.

The study area (Fig. 1) is located at subpolar latitude, in the mid North-Atlantic $\left(66^{\circ} \mathrm{N}-23^{\circ} \mathrm{W}\right)$. This northern location has both climatic and morphologic implications. As a subpolar oceanic climate, the weather in the northwestern part of Iceland is perturbed, as the area lies on the main low pressure trail, contributing to high temperature and precipitation variation over a short time period throughout the year. The superimposed basaltic lava flows of the area experienced Quaternary glacial conditions, during which the coastline was shaped into numerous and deep fjords. Thus, slopes are steep, and debris availability is high, due to large supplies in both inherited glacial products and actual frost shattering. The elevation varies from 400 to $700 \mathrm{~m}$, with flat summits. The slope upper part is steep, joining a rockwall. In the lower part are steep and slightly concave talus slopes. In some cases, a bench interrupts the upper rockwall, covered with a thick debris mantle. The upper edge is cut by numerous chutes, of varying width. Human settlements occupy the thin area between the sea and the mountain slopes. All these conditions are prone to snow-avalanche and debris-flow activity in the northwestern part of Iceland, and exacerbate the risk.

\section{Methods}

Spatio-temporal characteristics of both the slope processes under study and anthropogenic factors are particularly relevant in this study (Decaulne, 2004b, 2005). The spatial distribution of slope processes has been investigated around the main settlements of the Westfjords through geomorphological analysis, topography and aerial photographs 


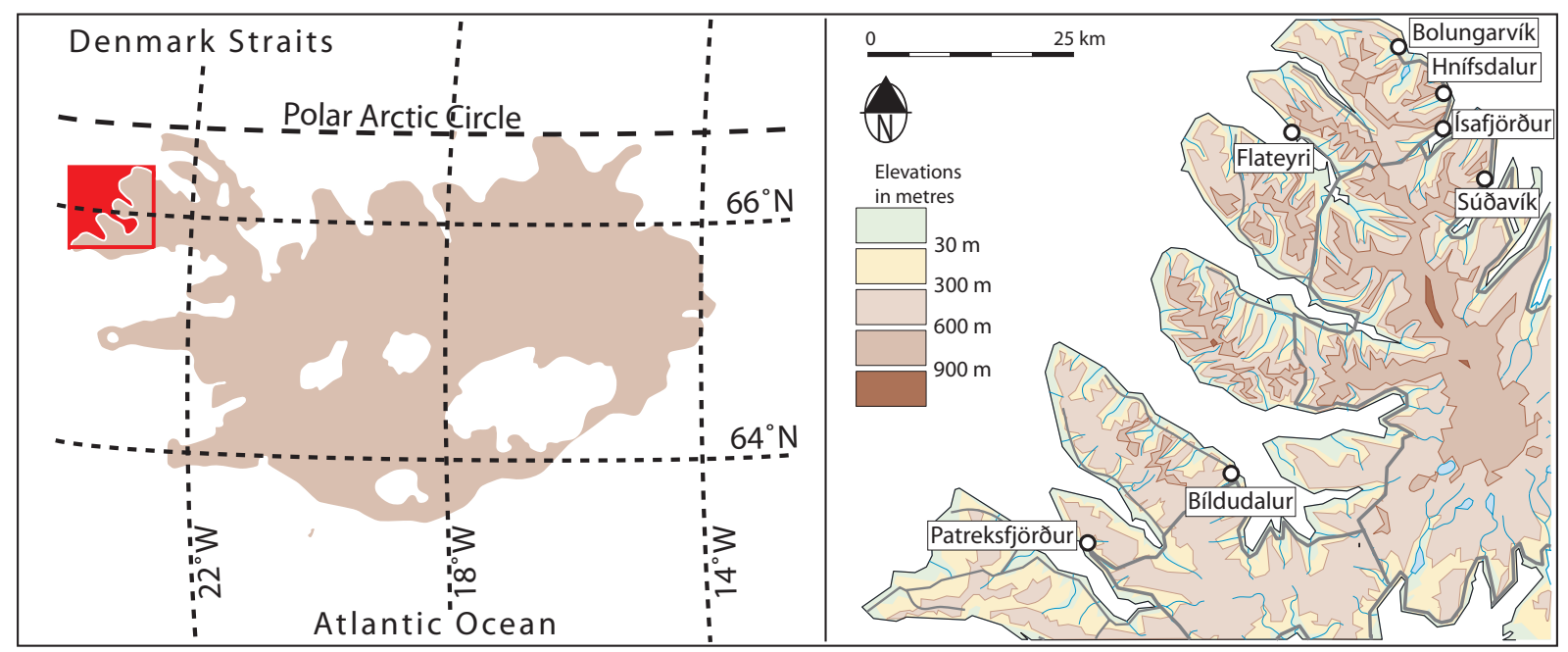

Fig. 1. Location of the study area.

Table 1. The number of potential snow-avalanche and debris-flow tracks in the five studied areas of the Icelandic Westfjords.

\begin{tabular}{lll}
\hline Sites & No. of snow avalanches & No. of debris flows \\
\hline Patreksfjordur & 9 & 18 \\
Bildudalur & 5 & 15 \\
Bolungarvik & 8 & 16 \\
Hnifsdalur & 5 & 17 \\
Isafjordur & 24 & 35 \\
\hline
\end{tabular}

Table 2. The snow-avalanche and debris-flow track density in the five studied areas of the Icelandic Westfjords.

\begin{tabular}{lll}
\hline Sites & $\begin{array}{l}\text { Snow-avalanche density } \\
\mathrm{km}^{-1}\end{array}$ & $\begin{array}{l}\text { Debris-flow density } \\
\mathrm{km}^{-1}\end{array}$ \\
\hline Patreksfjordur & 3.6 & 7.2 \\
Bildudalur & 2.8 & 8.6 \\
Bolungarvik & 4 & 8 \\
Hnifsdalur & 1.4 & 4.7 \\
Isafjordur & 11.4 & 16.6 \\
\hline
\end{tabular}

interpretation, various reports study, location and description of both erosive and accumulative landforms, drawing out snow-avalanche and debris-flow paths. Using this information, maps are drawn, showing the main tracks and the outline of the larger recognised runout distances.

The temporal distribution of slope processes is known with the help of absolute dating, primarily extracted from written sources such as slope processes reports, newspapers and chronicles that multiply during the twentieth century. Governmental institutions compiled most of these data (Agust- son et al., 2002, 2003a, b; Arnalds, 2002; Petursson, 1991, 1992a, b, 1995, 1996; Petursson and Saemundsson, 1999; Petursson and Jonsdottir, 2000a, b; Petursson and Jonsson, 2001). The use of lichenometry (Rhizocarpon geographicum species) and vegetal cover measurements provide relative dating of the deposits related to snow avalanches and debris flows (Decaulne, 2001b; Decaulne and Saemundsson, 2003).

The access to historical data, such as old maps and photographs, census, cadastral and local chronicles (Grimsdottir, 1999; Geirsdottir, 2000a, b, c), give precious information on human spatio-temporal distribution from the end of nineteen century in the studied villages and urban nuclei of the northwestern peninsula.

From a compilation of all deterministic and historic data, overall maps are drawn.

\section{Results}

\subsection{Slope processes spatial-temporal distribution}

Figure 2 underlines that all slopes in northwestern Iceland are subject to snow avalanches and debris flows; whatever slope orientation and elevation, snow-avalanche and debrisflow activity is observed. Both snow-avalanche and debrisflow tracks can be confined, when the track follows a deep gully in the upper part of the slope, or unconfined, when the slope is open, without marked gully. The number of potential paths, i.e. suitable for snow-avalanche and debris-flow release according to field assessments, is high in each site, but varies from one site to another (Table 1): from 9 to 24 paths for snow avalanches and from 15 to 35 paths for debris flows. Due to differences in sites extent, the path density calculation is more significant (Table 2). Thus, sites affected by snow avalanches are mostly Isafjordur and Bolungarvik, but no site is free from snow-avalanche recognised paths. All 
sites are severely affected by debris flows, Hnifsdalur in a smaller proportion than others.

Mainly derived from written sources, snow-avalanche (Fig. 3) and debris-flow (Fig. 4) occurrence in the five different localities underlines the scattered number of reported events through the last century, and the increasing number of documented events with time, specifically after 1980 . This observation is more marked for snow avalanches than for debris flows, which are more seldom announced by local population or authorities. Depending on the location, the snow-avalanche return period varies from 1.44 in Isafjordur to 7 years in Patreksfjordur, and the debris-flow return period varies from less than 1 year in Isafjordur to about 35 years in Patreksfjordur (Decaulne, 2004b).

\subsection{Human spatio-temporal distribution}

The human spatio-temporal distribution in the Westfjords urban nuclei and rural areas passed through radical changes since the 1880s. The population constantly grew up until the 1980s, when the number of inhabitants reaches its maximum (Fig. 5a). During the same period, the population density increased continually (Fig. 5b). Over this time, the population behaviour is closely dependent on economic situation, mainly related to fishing industry: in the small town of Bolungarvik, the decrease in population at the beginning of the last century is likely due to a local exodus of fishermen families towards other parts of the Westfjords, due the late construction of a wharf, while similar facilities were built in other places, allowing the docking of motorboats.

The building curves (Fig. 5c) show a different evolution, which increases in stages to reach its maximum during the 1980s, while the population is the most numerous. The building density shows the same growth (Fig. 5d), with a sudden increase during the 1970s and stabilisation during the 1980s. The first built areas are mainly scattered along the seashore, with subsequent expansion concentrated close to the sea (harbour constructions) and later extending to the mountain slopes, where more various economic activities are developing.

\subsection{Risk appearance}

When combining the slope processes and human data together, a spatial conflict appears. The inhabited areas extend to the slopes, while slope process deposit areas extend to the bottom of the slopes: the thin area close to the sea that is fit for residence is both influenced by human development and snow avalanches or debris flows. During the twentieth century, the increasing superimposition of human and natural activities at the foot of slopes has created an obvious problem, by exacerbating the risk. This scenario is common to all urban nuclei of the study area, but a more detailed examination of Patreksfjordur and Isafjordur diachronic maps illustrates the progressive appearance of risk due to slope processes, as the inhabited areas have been developed in locations that are influenced by natural processes.

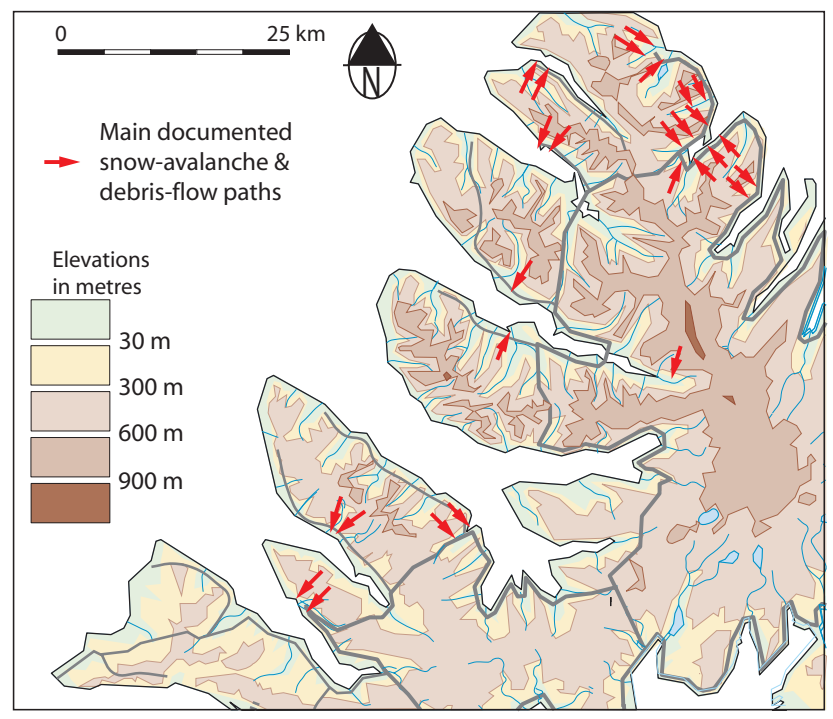

Fig. 2. Location of documented snow-avalanche and debris-flow paths in North-western Iceland (refer to figure 01 for the location of studied areas).

In 1900, Patreksfjordur (Fig. 6a) consisted of only a small amount of inhabitants, gathered together along the sea. Only two events were known at this time. In 1950 (B), some more events were registered, especially two snow avalanches that reached the sea in the harbour area, and a debris flow that reached the uppermost houses on the main road. By 1980 (C), the town had grown, and the areas that were crossed by slope processes along the sea were from then on clearly occupied with residential and industrial buildings. Since 1980 the inhabitant and building density had increased and more events were recorded, especially two slush flows that caused 4 fatal accidents (D).

This pattern of evolution is more or less equivalent in Isafjordur. In 1900, it was rather a small village of 500 people, gathered together on the gravel spit (Fig. 7a). No snow avalanches or debris flows were recorded then. In 1950 (B), the settlement extended to the bottom of slope, and inside the valley to the southwest. In 1980 (C), the density of population increased on the lower slope of the main part of the town; moreover, a residential area was built at the bottom of a $400 \mathrm{~m}$ high slope. More debris-flow and snow-avalanche events were recorded. In 2003 (D), a larger number of snow avalanches and debris flows were recorded, and the dangerous areas, i.e. where snow-avalanche and debris-flow deposit area superimposes the residential area, are wide.

This inhabitant behaviour evolution in the Westfjords reflects changes in Icelandic society: the smaller rural settlements gradually coalesced into coastal lowland growing urban nuclei (Decaulne, 2004a). Thus, vulnerability increased with community spatial development along the fjord seashore, and is a measurable factor of social change (Bankoff, 2003). 


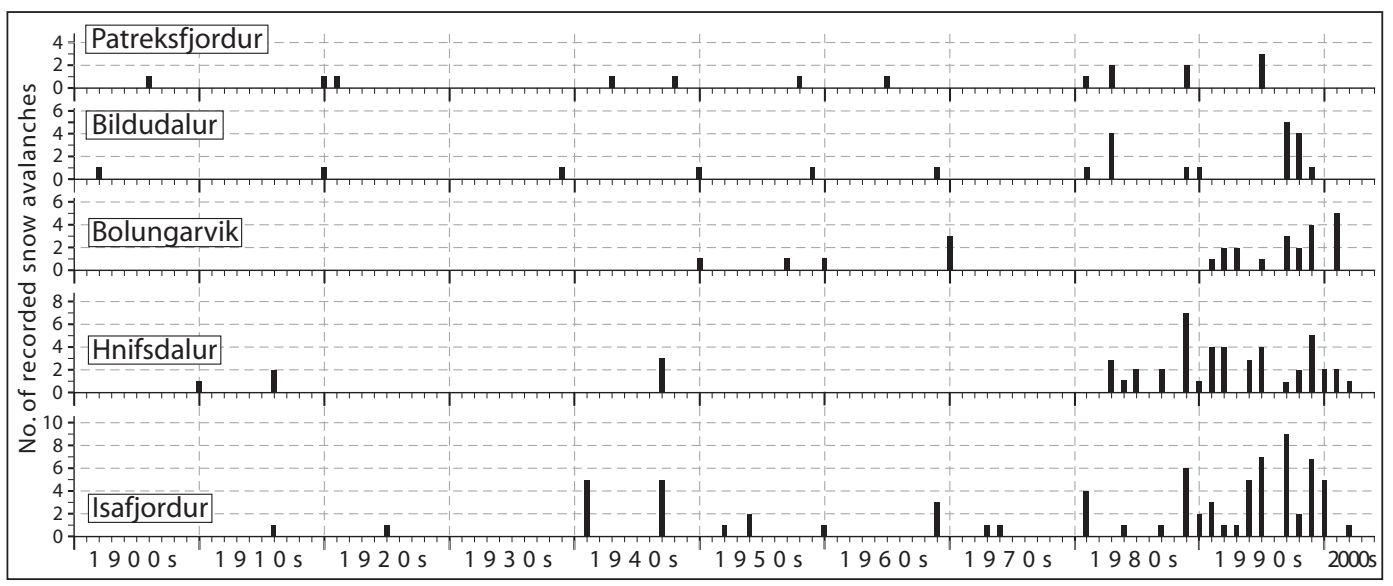

Fig. 3. Snow-avalanche temporal distribution in North-western Iceland.

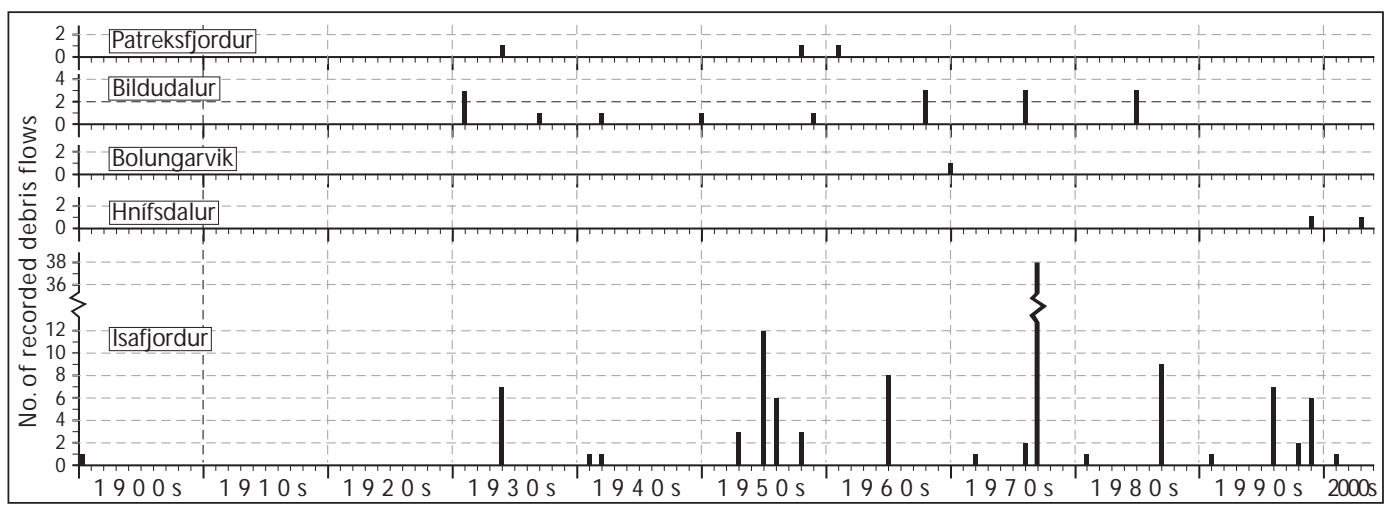

Fig. 4. Debris-flow temporal distribution in North-western Iceland.

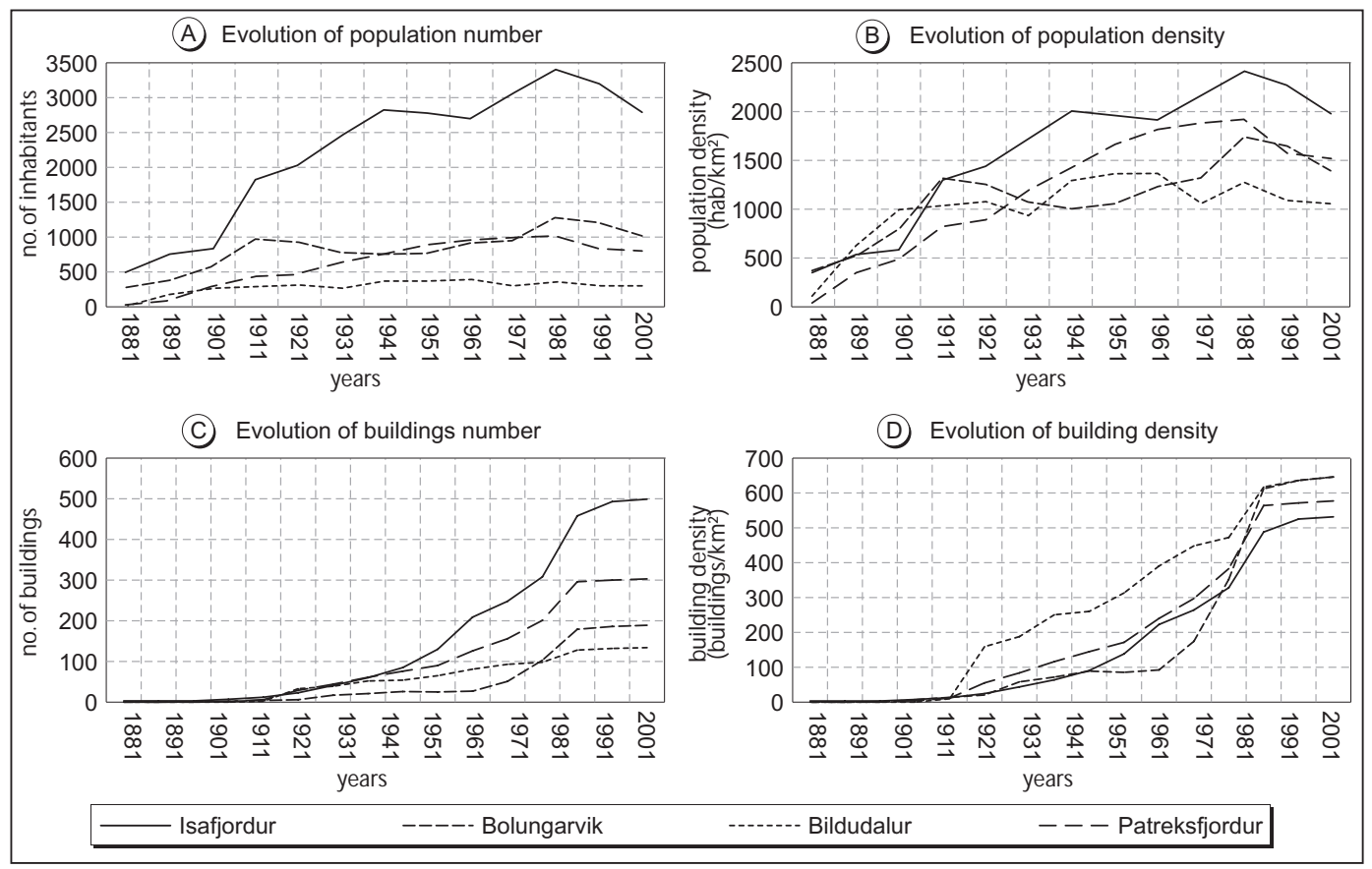

Fig. 5. Human spatio-temporal distribution in North-western Iceland. 


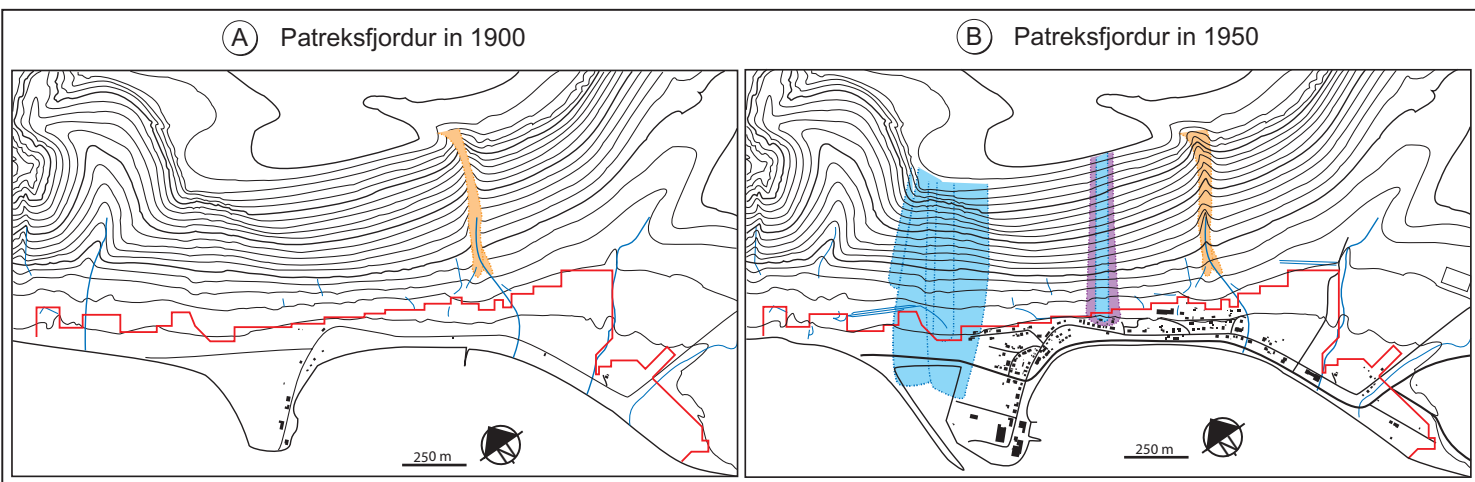

(C) Patreksfjordur in 1980

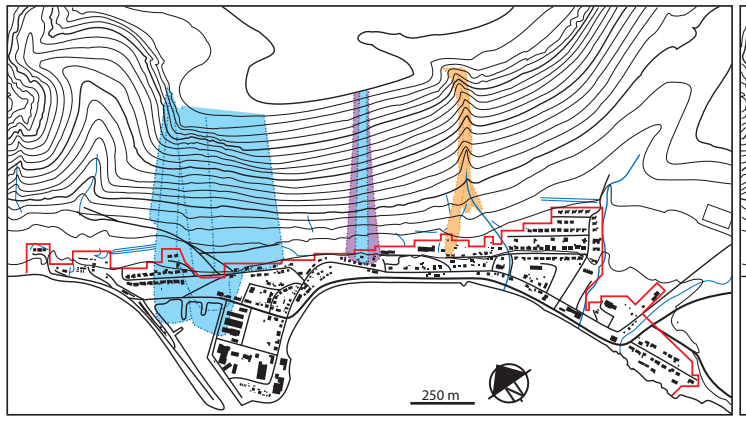

(D) Patreksfjordur in 2003

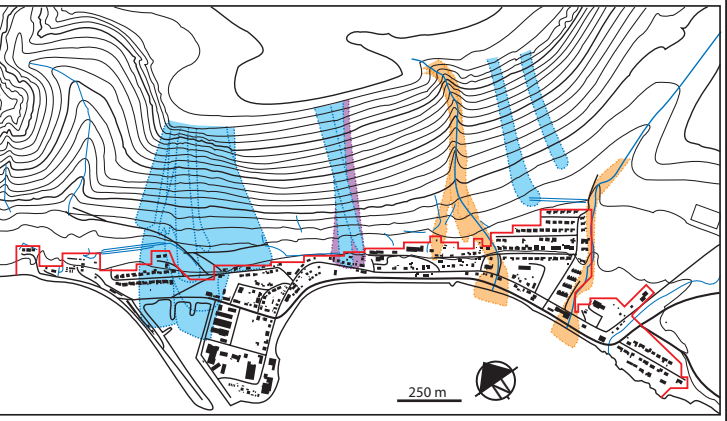

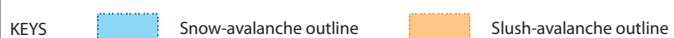

Debris-flow outline Inhabited area

Contour lines $=20 \mathrm{~m}$

Fig. 6. Diachronic maps of the site of Patreksfjordur.

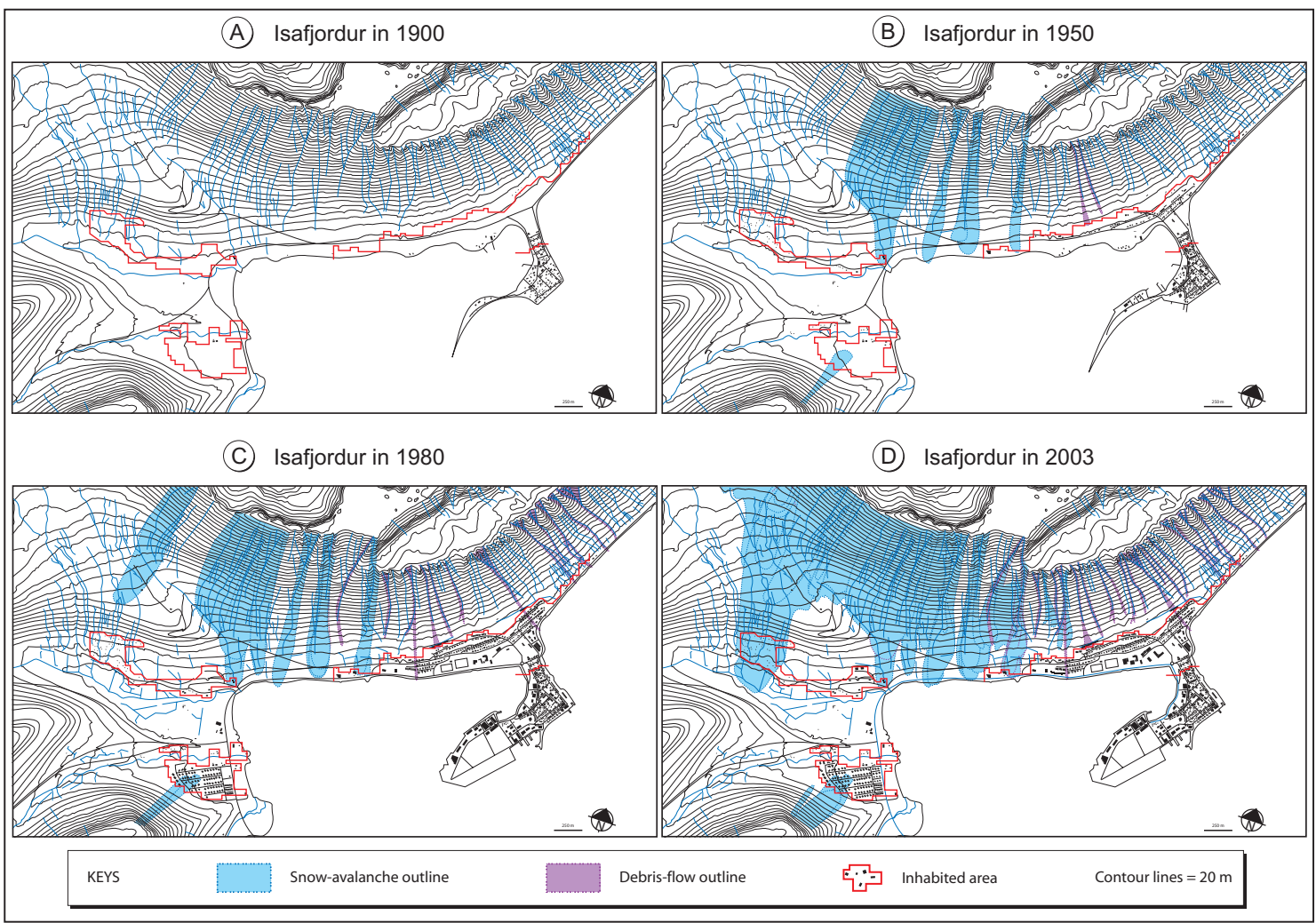

Fig. 7. Diachronic maps of the site of Isafjordur. 


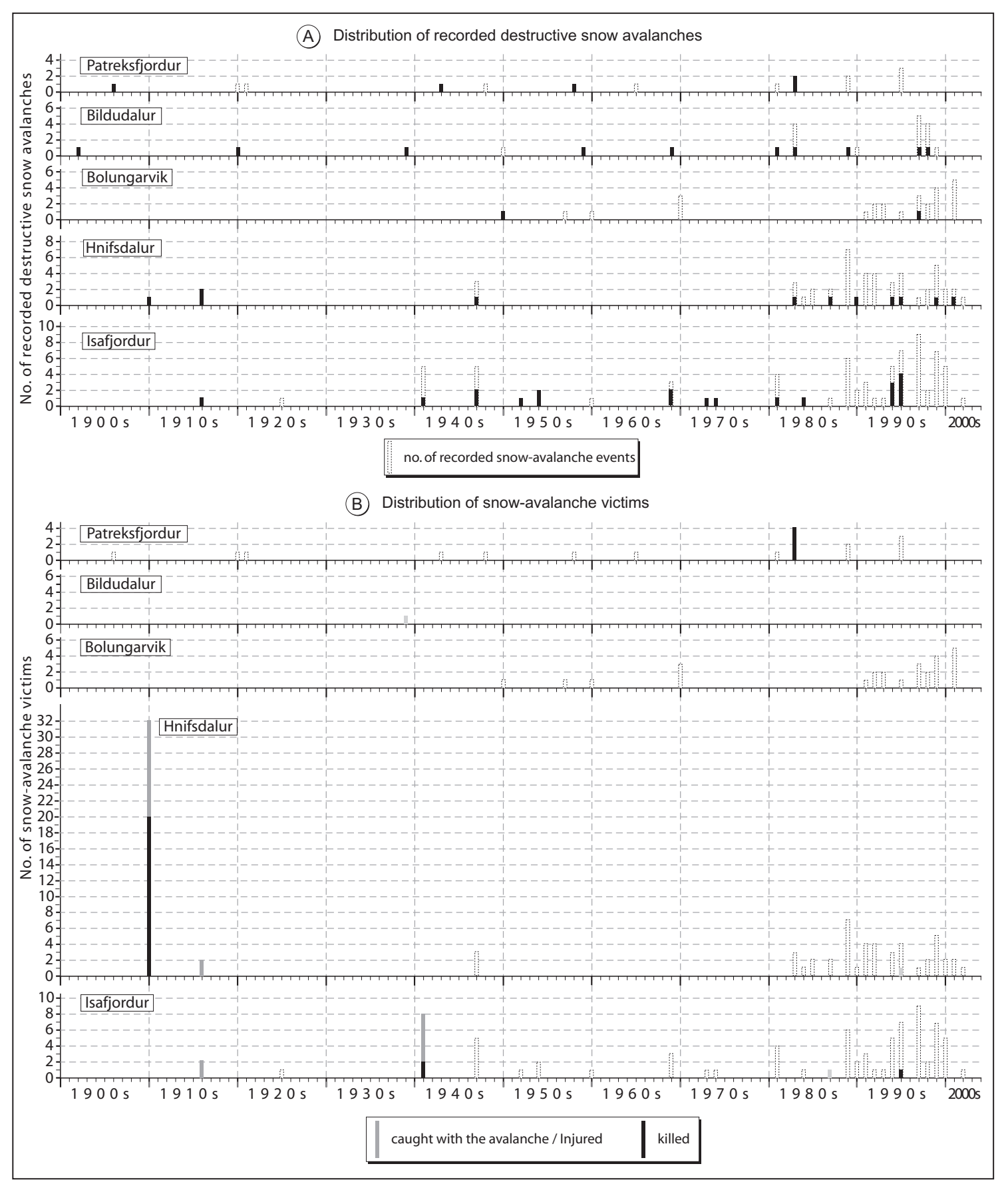

Fig. 8. Recorded destructive and fatal snow avalanches in North-western Iceland.

\section{Discussion}

From the presented results, an obvious risk situation arose during the second half of the last century. This situation is due to a combination of snow-avalanche/debris-flow activity and residence location. Nevertheless, the increasing number of recorded events with time during the 20th century could be explained by the increasing land occupation during the same period, as both trends are parallel: at the beginning of the 20th century, people moved from place to place more than they did before, as commercial exchanges and fishing industry grew; moreover, from the 1940s, people reside in areas that were previously uninhabited, and residents noticed more events while they became more susceptible to slope processes because of snow-avalanche and debris-flow deposits in fields, material or human damages. Then, the number of documented or reported events is a function of the population density in a specific area.

When looking at this situation from a dynamic point of view, a catastrophic scenario is easy to imagine. People 


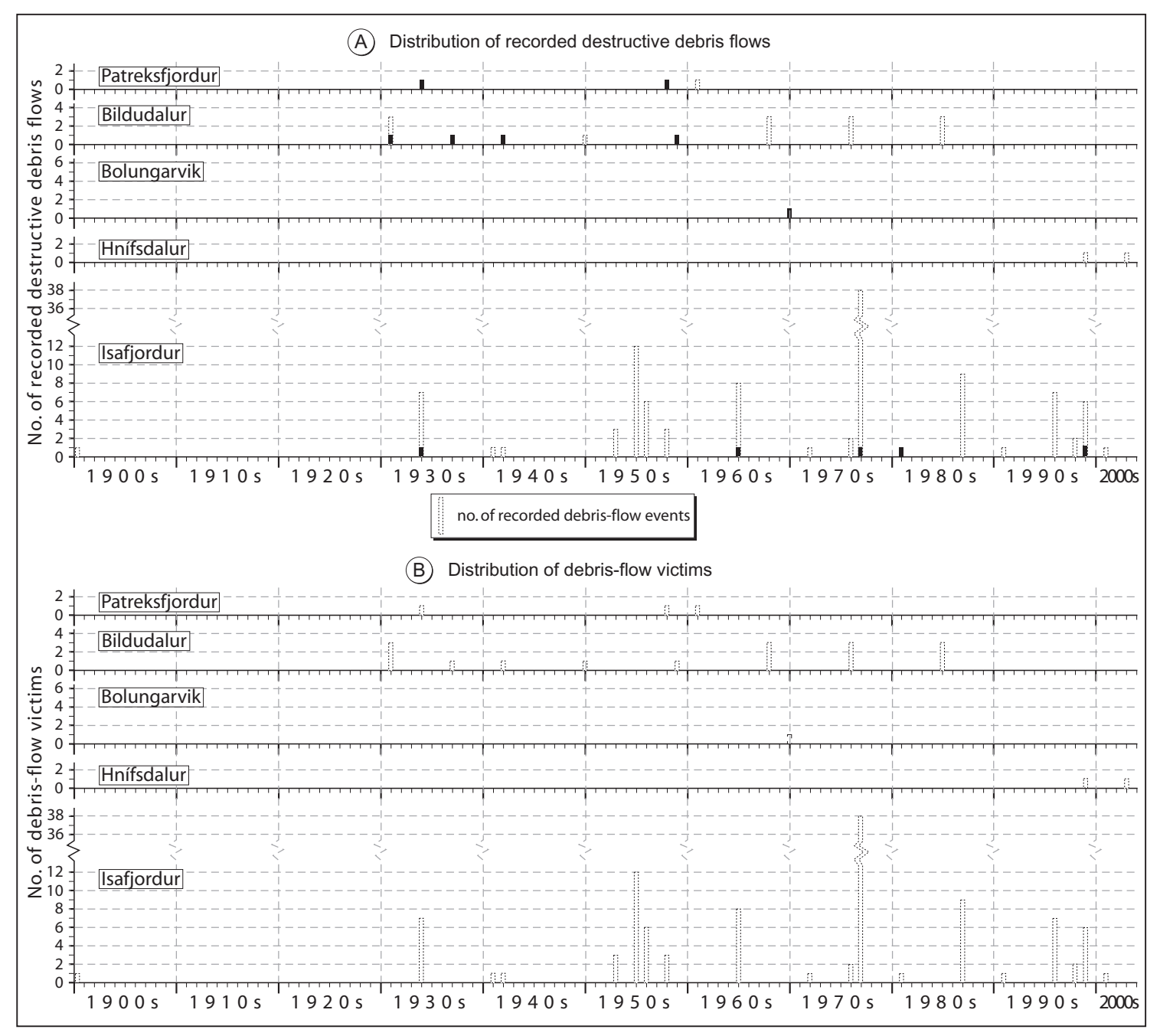

Fig. 9. Recorded destructive and fatal debris flows in North-western Iceland.

are putting themselves in danger because they do not understand the natural slope activity, despite the numerous landforms visible on slopes that clearly indicate that snow avalanches and debris flows are active (Decaulne, 2001a, b, 2002, 2003; Decaulne and Saemundsson, 2003; Saemundsson et al., 2003). At this stage, it seems obvious that the impact of slope processes on different people is different according to different perceptions and points of view, for the geomorphologist, the slope processes impact on population, so vulnerability and risk is a combination of occurrence frequency and magnitude. For the inhabitants, the risk is a question of calamitous events frequency. Then, without going far into psychological aspects, the risk perception is different according to social or geomorphic issues (Rohrmann, 1999). Here, a comparative study is undertaken on the five sites, highlighting the number of recorded destructive snow avalanches, i.e. those that caused material damages (broken fences, houses, cars), and number of recorded fatal snow avalanches (Fig. 8). The same study is carried out for debris flows, underlining the low number of destructive events and the absence of victims (Fig. 9). Two observations can be made: (1) fatal accidents were very rare and scattered during the last century, and (2) the construction period was very calm. Then the impact of slope processes was very low on inhabitants. Moreover, the debris flow impact is lower than that of snow-avalanches, in term of risk understanding. This situation is worsened by the scattered direct impact on local population, which puts a curb on risk awareness.

Regarding the construction period, from 1940 to 1980, it corresponds to the most favourable climatic space of time: on figure 10, the climatic trends from 1823 in the oldest meteorological station of Iceland, Stykkisholmur, in the northern bank of the Snaefesllnes peninsula (75-100 km from the study area), are shown. The trend is parallel to that from Westfjords data, where the temperature values are $0.5^{\circ} \mathrm{C}$ lower. The mean annual temperature (A) rose more than $1{ }^{\circ} \mathrm{C}$ from the 1920 s to the 1970 s. The mean annual precipitation evolution (B) increased during two-three decades (1920s-1940s), and then decreased noticeably. During this time, the mean annual atmospheric pressure (C) slowly increased, while temperature rose and precipitation lessened. The upper part of the Fig. 10 give a brief statement of the 


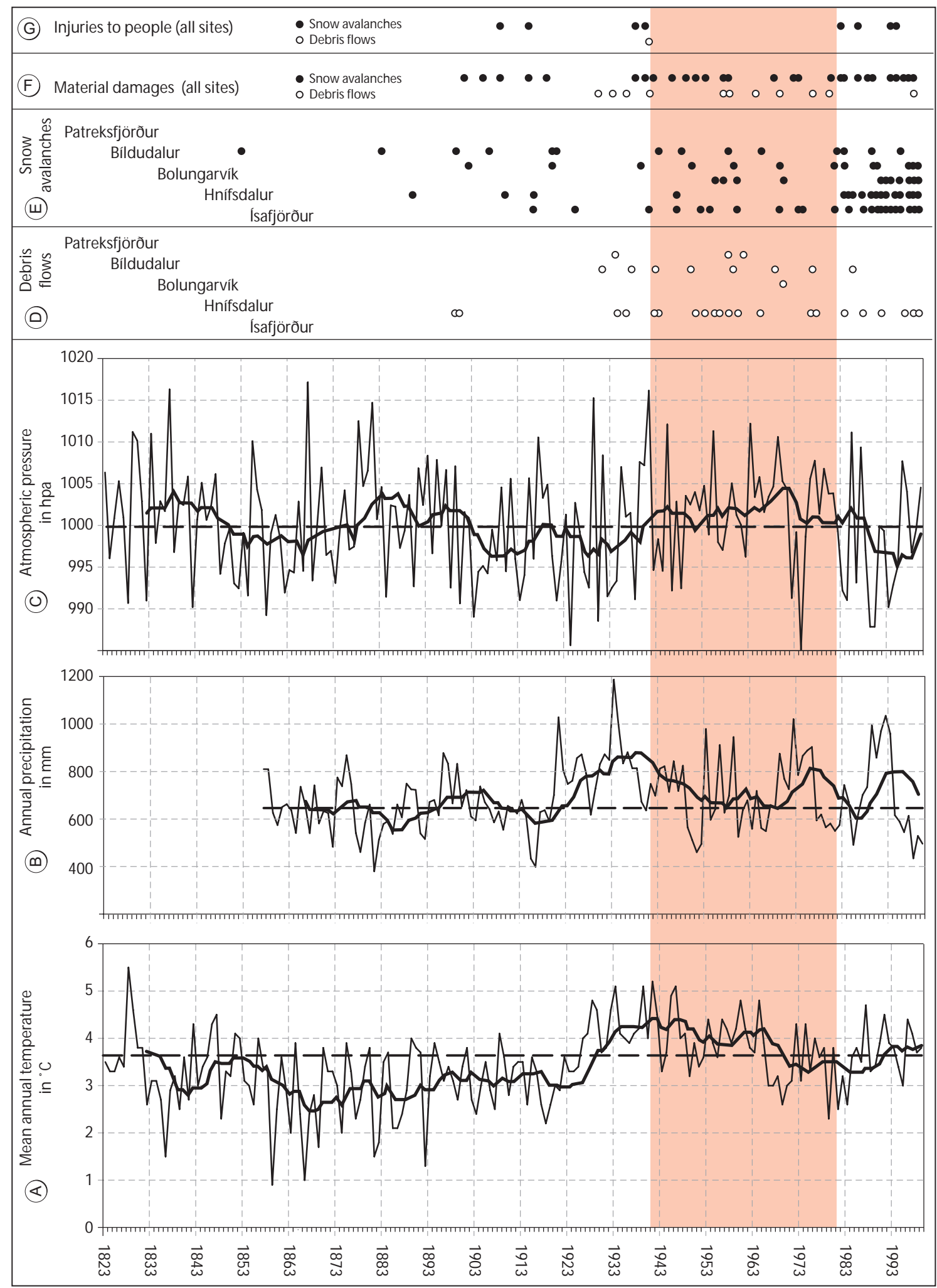

Fig. 10. Climate evolution, urban areas and risk relationship in North-western Iceland. The vertical coloured strip refers to the settlement expansion period. 
main points of this study, highlighting that the larger number of events is recorded at the end of the 20th century (D, E), that material damages and accidents are scattered $(\mathrm{F})$, and that injuries to people caused by slope processes $(\mathrm{G})$ are even more seldom. Just before the settlement expansion (1920-1940), temperatures were rising, so precipitation was likely to be less snowy and major avalanches have not been recorded. Local events occurred. The next period (19401980) was particularly favourable for settlement expansion, as previously mentioned, in terms of the weather. Moreover, if snow avalanches and debris flows were reported, this period did not record any fatal accidents, which could have discouraged the settlements on lower parts of slopes. It is only at the end of this period that fatal accidents occurred, together with lower temperatures and atmospheric pressures, and higher precipitation. Nevertheless, more studies are necessary to estimate and predict the influence of future climate trends and changes on slope processes, and then risk implications, in this area.

\section{Conclusion}

The progressive appearance of risk, and the observed risk situation in the Icelandic Westfjords are not unusual: the occurrence of slope processes was unknown before the settlement expansion in most places, and, during the expansion period, the low frequency of extreme events combined with the economic expansion of the area, did not help a popular awareness of danger.

But today, at the beginning of the 21th century, most of the localities of northwestern Iceland are comparatively wellprotected in terms of the inhabitants. This quick turnaround is the consequence of a sudden awareness of risk by the local inhabitants and the national authorities. This could be due to 3 fatal accidents in a range of $15 \mathrm{~km}$ around Isafjordur during 3 successive winters: in Isafjordur, in early April 1994, the Tungudalur snow avalanche caused the death of one person, and the destruction of more than 30 summerhouses; in the village of Sudavik, in mid-January 1995, 14 people lost their lives (almost $1 / 10$ of the population); in Flateyri, in midOctober 1995, 20 people lost their lives (almost 1/10 of the population).

This raises the question of risk acceptance (Fischhoff et al., 1981; Rohrmann, 1998) by individual and society: before 1995, damages were mainly material, and fatal accidents were rare. After the catastrophic year in 1995, efforts were made to mitigate the risk, especially the risk due to snow avalanches, as they are more frequent than debris flows and have caused severe damage in several communities.

Acknowledgements. Part of this study was supported by the Laboratory of Physical Geography Géolab CNRS-UMR 6042 and Réseau Arctique. Valuable discussions with T. Saemundsson are gratefully acknowledged. Thanks are also due to H. G. Petursson, T. Johannesson, O. Petursson, T. Jonsson and H. Grimsdottir, who greatly facilitated access to helpful documents. T. Glade and M. Crozier are acknowledged for their review and comments on the manuscript, and F. Tweed is thanked for the substantial improvement of the English text.

Edited by: T. Glade

Reviewed by: M. Crozier

\section{References}

Agustsson, K., Johannesson, T., Sauermoser, S., and Arnalds, Th.: Hazard zoning for Bolungarvik, Technical report, Icelandic Meteorological Office, VI-UR19, 2002.

Agustsson, K., Johannesson, T., Sauermoser, S., and Sigurdsson, H. Th.: Hazard zoning for Patreksfjordur, Vesturbyggd, Technical report, Icelandic Meteorological Office, VI-UR20, 2003a.

Agustsson, K., Johannesson, T., Sauermoser, S., Sigurdsson, H. Th., and Jensen, E. H.: Hazard zoning for Bildudalur, Vesturbyggd, Technical report, Icelandic Meteorological Office, VIUR23, 2003b.

Arnalds, Th., Sauermoser, S., Johannesson, T., and Grimsdottir, H.: Hazard zoning for Isafjordur and Hnifsdalur, Technical Report, Icelandic Meteorological Office, VI-UR15, 2002.

Bankoff, G.: Vulnerability as a measure of change in society, International Journal of Mass Emergencies and Disasters, 21, 20-30, 2003.

Decaulne, A.: Mémoire collective et perception du risque lié aux avalanches et aux debris flows dans les fjords islandais : l'exemple du site d'Isafjordur (Islande nord-occidentale), Revue de Géographie Alpine, 89, 63-80, 2001a.

Decaulne, A.: Dynamique des versants et risques naturels dans les fjords d'Islande du nord-ouest, l'impact géomorphologique et humain des avalanches et des debris flows, PhD Thesis, University of Clermont II, France, 2001b.

Decaulne, A.: Coulées de débris et risque naturels en Islande du nord-ouest, Géomorphologie, 2, 151-164, 2002.

Decaulne, A.: Réalité et perception des risques naturels liés à la dynamique des versants dans les fjords d'Islande du nord-ouest, Bull. Ass. Géogr. Fran., 4, 394-400, 2003.

Decaulne, A. and Saemundsson, Th.: Debris-flow characteristics in the Gleidarhjalli area, northwestern Iceland, in: Debris-Flow Hazards Mitigation: Mechanics, Prediction, and Assessment, edited by: Rickenman, D. and Chen, C. I., Millpress: Rotterdam, 1107-1118, 2003.

Decaulne, A.: Le risque avalancheux en Islande, Bull. Ass. Géogr. Fran., 1, 75-83, 2004a.

Decaulne, A.: Combining geomorphological, historical and lichenometrical data for assessment of risk due to present-day slope processes, a case study from the Icelandic Westfjords, in: Risk Analysis 4, edited by: Brebbia, C. A., WIT Press: Southampton, 177-186, 2004b.

Decaulne, A.: L'apport des données géomorphologiques et historiques à l'analyse diachronique du couple aléa-vulnérabilité dû aux avalanches et aux coulées de débris dans les fjords d'Islande nord-occidentale, Norois, 1, in press, 2005.

Fischhoff, B., Lichtenstein, S., Slovic, P., Derby, S. L., and Keeney, R. L.: Acceptable risk, University Press: Cambridge, 1981.

Grimsdottir, H.: Byggingarar husa a Isafirdi, Icelandic Meteorological Office, VI-G99014-UR08, 1999.

Geirsdottir, S.: Byggingarar husa a Bildudal, Natural Research Centre of the Icelandic Westfjords of, NV6-00, 2000a.

Geirsdottir, S.: Byggingarar husa a Patreksfirdi, Natural Research Centre of the Icelandic Westfjords, NV78-00, 2000b. 
Geirsdottir, S.: Byggingarar husa a Bolungarvik, Natural Research Centre of the Icelandic Westfjords, NV8-00, 2000c.

Petursson, H.G.: Drög ad skriduannal 1971-1990, Icelandic Museum of Natural History, 14, 1991.

Petursson, H. G.: Skriduannall 1951-1970, Icelandic Museum of Natural History, 16, 1992a.

Petursson, H. G.: Skriduannall 1991-1992, Icelandic Museum of Natural History, 17, 1992b.

Petursson, H. G.: Skriduannall 1993-1994, Icelandic Museum of Natural History, 2, 1995.

Petursson, H. G.: Skriduannall 1925-1950, Icelandic Museum of Natural History, 3, 1996.

Petursson, H. G. and Saemundsson, Th.: Skriduföll a Isafirdi og i Hnifsdal, Icelandic Museum of Natural History, NI-99010, 1999.

Petursson, H. G. and Jonsdottir, H. E.: Skriduannall 1900-1924, Icelandic Museum of Natural History, NI-00018, 2000a.
Petursson, H. G. and Jonsdottir, H. E.: Skriduannall 1995-1999, Icelandic Museum of Natural History, NI-00019, 2000b.

Petursson, H. G. and Jonsson, H. B.: Skriduannall 2000, Icelandic Museum of Natural History, NI-01026, 2001.

Rohrmann, B.: Risk perception research - Review and documentation, Research Center Juelich, RC Studies no. 68, 1999.

Rohrmann, B.: The risk notion: epistemological and empirical considerations, in: Integrated Risk Assessment, edited by: Stewart, M. G. and Melchers, R. E., Balkema: Rotterdam, 39-46, 1998.

Saemundsson, Th., Petursson, H. G. and Decaulne, A.: Triggering factors for rapid mass movements in Iceland, in: DebrisFlow Hazards Mitigation: Mechanics, Prediction, and Assessment, edited by: Rickenman, D. and Chen, C. I., Millpress: Rotterdam, 167-178, 2003. 